\title{
WOMEN WITH DISABILITIES AND EMPOWERMENT
}

\author{
Sukhwinder Kaur (JRF) \\ Department of Community Education and Disability Studies, Panjab University, Chandigarh \\ India
}

\begin{abstract}
Women and girls with disabilities have always been remained at the margin of the society. They have not been given equal rights and status and have always faced discrimination in all spheres of life from the society. In today's world where we all talk about women empowerment, women and girls with disabilities still remain marginalized by the society. They are considered unproductive and unwanted for the society. But they are also an important part of the main society and needed to be empowered for the betterment of the society and as well as of the whole nation. Women and girls with disabilities need to be renowned as individuals who enjoy the equal rights and status as other members of the society to make decisions about their lives. It is only through education they can be empowered. Women empowerment is the ability of women to enjoy equal rights, take their own decisions and to improve their total well-being. The main objective of the present study is to suggest the ways for empowering the women with disabilities and to discuss the different barriers in the way to their empowerment.
\end{abstract}

Key words: Disabilities and Empowerment

\section{INTRODUCTION}

One in five women lives with different kinds of disabilities and the frequency of disability is very high among women as compared to men (19.2 versus 12 per cent). According to the World Health Organization; Disability is an umbrella term which includes impairments, activity limitations, and participation restrictions, impairment is a problem in body function of structure; an activity limitation is difficulty encountered by an individual in executing a task or action; while a participation restriction is a problem experienced by an individual in involvement in life situations (http://www.who.int/topics/disabilities/en/). Thus disability is a complex phenomenon which creates hindrance in the path of individual's life and restricts a person's over all activities.

Disability among women is larger than men. Lower social and economic status of women and girls, gender-based violence and hurtful or gender-discriminatory practices etc. are the major contributing factors for this (Empowering and including women and girls with disabilities, December 2015). Women and girls with disabilities remain at the margin of decision making. Women and girls with disabilities are especially vulnerable to abuse in all forms: physical, sexual, emotional and psychological (Empowering women with disabilities, 2004). They face discrimination in all spheres of life by the society and even neglected by their family members. Women and girls with disabilities are considered burden on family as well as on society. They are deprived of their rights and are not provided equal and fair opportunities. However they are also important part of society and should get equal treatment as the other members of the society. They also need empowerment for the betterment of their lives. Empowerment is the ability of any person who can take his/her own decisions, enjoys equal rights, work towards the betterment of the life etc. According to the UN Convention on the Rights of Persons with Disabilities (CRPD), article 6 - Women with disabilities requires that states parties which shall take all appropriate measures to ensure the complete development, advancement and empowerment of women, for the purpose of guaranteeing them the exercise and enjoyment of the human rights and fundamental freedoms (https://sustainabledevelopment.un.org/getWSDoc.php?id=3135). The UN Convention on the Rights of Persons with Disabilities (CRPD) lays emphasis on mainstreaming of women and girls with disabilities into the society in which they can live their lives with respect and dignity. The women with disabilities need the empowerment in the following fields: (i) Social Empowerment: This means women with disabilities enjoys equal rights, gets equal opportunities and lead social life with dignity in society. (ii) Economic Empowerment: Economic empowerment refers to the capacity for women to enjoy their rights to manage and profit from resources, possessions, revenue and their own time, as well as the ability to handle risks and improve their financial status and wellbeing (Oxfam (Forthcoming)). (iii) Gender Empowerment: Gender empowerment means equality on the basis of gender and absence of discrimination. 


\section{REVIEW OF LITERATURE}

Shettar, R. M. (2015) in her study analyzed the status of Women Empowerment in India and highlighted the Issues and Challenges of Women Empowerment. Major findings of the study revealed that women of India are not much empowered as compared to the men and they enjoy rather lower status than that of men in spite of many efforts undertaken by Government and NGOs. The study also found that acceptance of unequal gender status by women is still prevailing in Indian society. The study concluded that access to Education, Employment and Change in Social Structure are the enabling factors to Women Empowerment. Aggarwal, M. (2014) in his study "A Study on Challenge for Women Empowerment" revealed that Education is the most powerful tool for attaining women empowerment in the society. The study also revealed that higher education plays an important role in women's life to meet the challenges of the present complex world. Sonowal, M. K. (2013) researched that modern education and amenities have influenced women empowerment. But still rural women in Sonitpur district are lagging behind in comparison to women living in urban areas. Women belonging to SC, ST communities living in village areas are less empowered as compared to general women living in these places. The women lag behind in social, political and economical spheres of life. The results of the study also revealed that this backwardness is also hampering the rural development. Duflo, E. (2011) in study named "Women's Empowerment and Economic Development", revealed that Women's empowerment and economic development are closely related and empowering women may benefit development. The study argued that the relationship between Empowerment and Development are perhaps too weak to be self sustaining and that continuous policy assurance to equally for its own sake may be needed to bring about equality between men and women. Nayak, P \& Mahanta, B. (2009) studied "Women Empowerment in India". The results of this study revealed that women are less empowered in India, enjoy lower social status than men, women justify wife beating, fewer women have final saying on how to spend earnings, less exposure to media than males, rural women are more prone to domestic violence as compared to urban women and gender gap exists in the political participation. Although a number of studies on women empowerment are available but not much work has been done in the field of empowerment of women with disabilities. That is why the researcher has taken up the present study named "Women with Disabilities and Empowerment".

\section{NEED OF THE STUDY}

It is a right of every person to live his/her life with dignity and equal opportunities. Women and girls with disabilities are not the exception as they are also the part of the society. Since ages they have been denied of their rights and equal treatment. They are facing discrimination in all places by the society. Unemployment is also the major problem among the women with disability. The United Nations estimates that 75 percent of women with disabilities are unemployed. Women with disabilities who are working often paid less than their male counterparts and women who do not have disabilities. In education system also gender disparities exists. While the overall literacy rate for persons with disabilities is 3 percent, UNESCO estimates that it is just 1 percent for women and girls with disabilities (https://www.usaid.gov/what-we-do/gender-equality-and-womensempowerment/women-disabilities). They are not provided proper health care facilities, maltreated and even face many forms of violence. It is the need of the hour to provide them education, equal rights and opportunities. This is possible only if work is initiated to empower them through education and proper facilities. Though the Government and NGOs are doing their work to empower women with disabilities but a lot more has to be done in this field. If society wants to develop and progress, it is necessary to empower women with disabilities with the other members of society. Women with disabilities need economic and social empowerment necessarily so that they can earn their livelihood on their own and work for the betterment of the society.

\section{OBJECTIVES}

- To study the empowerment of women with disabilities

- To suggest the ways to empower the women with disabilities

- To discuss the barriers in the path of empowerment of women with disabilities

\section{GOVERNMENT SCHEMES AND STEPS TO EMPOWER WOMEN WITH} DISABILITIES

1. Rehabilitation Council of India Act, 1992 deals with the development of manpower (men and women) for providing rehabilitation services. There are five Composite Rehabilitation Centres, four Regional Rehabilitation Centres and 120 District Disability Rehabilitation Centres (DDRCs) providing various kinds of rehabilitation services to persons with disabilities. There are also several national institutions under the Ministry of Health and Family Welfare working in the field of rehabilitation (National Policy for Persons with Disabilities, 2006). Several Government programmes have been undertaken to rehabilitate abandoned 
disabled women/ girls by encouraging their adoption in families, support to house them and impart them training for gainful employment skills (https://en.wikipedia.org/wiki/Rehabilitation_Council_of_India).

2. Persons with Disability (Equal Opportunities, Protection of Rights and Full Participation) Act, 1995. This act includes women with disabilities as well, which provides for education, employment, creation of barrier free environment, social security, etc. (http://newsonair.nic.in/PWD_Act.pdf).

3. The Persons with Disability Act, 1995 provides for 3\% reservation for both men and women in employment in the establishments of Government of India and Public Sector Undertakings (PSUs) against identified posts. Vocational and Skill training Centres have also been set up to employ them in private sector (National Policy for Persons with Disabilities, 2006).

4. Steps have been taken to provide short duration stay homes for women with disabilities, hostels for working disabled women, and homes for aged disabled women.

5. National Policy for the Empowerment of Women (2001) includes the women with disabilities to provide equal rights, opportunities, access to resources etc. to uplift their status in society.

\section{METHODS TO EMPOWER WOMEN WITH DISABILITIES}

Though the Government has taken many steps and made schemes for disabled women but still a lot more needs to be done. Some methods are given below:

1. Education: Women with disabilities have always been denied of their right to education. In India education is a Fundamental Right (Article-21 A) which includes the persons with disabilities as well. Education is a powerful mean through which women with disabilities can be empowered. The first and the most important thing which is to be done to empower to women with disabilities to give them equal opportunities for education. Education can be given in three forms:

(i) Formal Education: It means they should be welcomed in schools, colleges, universities etc. The Government should take steps to ensure formal education is given to the women with disabilities.

(ii) Informal Education: Family and society should provide informal education to women with disabilities to improve their social skills, so that they can live social life with ease.

(iii) Non-formal Education: Distance courses, e-learning and web based learning should be accessible to the women with disabilities.

2. Equal Rights and Opportunities: Equality means everybody get equal opportunities in every sphere of life without any discrimination. Women with disabilities should get equal rights as enjoyed by the other members of the society. Indian Constitution provides right to equality (Article 14-18) to all its citizens without any discrimination. It is the duty of the Government to check that nobody should deny right to equality to women with disabilities.

3. Economic Empowerment: This refers to equal economic rights. Women with disabilities should be able to control their assets, free to spend their earnings and should take economic decisions on their own.

4. Vocational Training: Government and NGOs should take more steps to provide vocational training to women with disabilities according to their interests and abilities. Vocational training centers should be accessible for these women. This will provide them chance to earn their livelihood on their own and they will not be dependent on any person for their expenses.

5. Placements at Working Places: After providing vocational training to women with disabilities they should be placed at working places according to their capabilities.

6. Gender Empowerment: Women with disabilities should be treated equally as of men. They should not be treated as weaker sex or non-productive part of the society. It is the duty of Government and the citizens to remove gender inequality from the society.

7. Social Media: In today's world social media is the most powerful platform to promote anything at anytime. This can be used to make people aware about the need to empower women with disabilities. The women with disabilities can also use this platform to organize campaigns or raise their voices for their equal rights and opportunities in the society.

\section{BARRIERS IN THE PATH OF EMPOWERMENT OF WOMEN WITH DISABILITIES}

There are many barriers which are posing hindrance in the path of empowerment of women with disabilities. The major barriers are as follows:

1. People's negative attitude: The major barrier in the path of empowerment of women with disabilities is the negative attitude of the people. They do not accept them as the part of the society even the family members of the women do not accept them as the part of their families.

2. Inaccessibility of Educational and Vocational Centers: Though Government has opened many educational and vocational centers for women with disabilities but in far rural and hilly areas these centers are still inaccessible for women with disabilities. 
3. Lack of awareness among Women with Disabilities: There is lack of awareness among women with disabilities about their rights, Government Schemes and NGOs. They are not aware about different vocational and educational centers near their homes.

4. Exploitation: Women with disabilities are exploited physically, mentally, sexually, financially and psychologically. This poses as a threat to their lives as well as poses as hindrance in their path of empowerment.

\section{SUGGESTIONS}

1. People's attitude needs to be change through campaigns, seminars, rallies etc. and they needs to be sensitized towards the women with disabilities.

2. Educational and vocational centers should be easily accessible to women with disabilities.

3. Awareness should be created among women with disabilities about their rights and about special schemes made by the Government for them.

4. Strict laws should be made and implemented to punish those who exploit women with disabilities in any manner.

5. Placement of women with disabilities in working sectors should be done on priority basis.

6. Social media may be used as platform for creating awareness among people about women with disabilities.

\section{CONCLUSION}

Women are the important part of society and one cannot imagine a society without women. Women with disabilities are also imperative for society and if provided proper education, vocational training and placed in working sectors can be proved productive for the society. In today's time people need to be sensitized towards them and needs to respect their individuality and dignity.

\section{REFERENCES}

[1] Aggarwal, M. (2014). A Study on Challenge for Women Empowerment. Retrieved from http://abhinavjournal.com/journal/index.php/ISSN-2277-1166/article/viewFile/276/pdf_56

[2] Definition of Disability. Retrieved from http://www.who.int/topics/disabilities/en/).

[3] Duflo, E. (2011). Women's Empowerment and Economic Development, National Bureau of Economic Research, Cambridge. Retrieved from https://ideas.repec.org/p/nbr/nberwo/17702.html

[4] Empowering and including women and girls with disabilities, (December 2015). Retrieved from http://www.unwomen.org/en/news/stories/2015/12/empowering-and-including-women-and-girls-withdisabilities\#sthash.36Zs1633.dpuf

[5] Empowering women with $\quad$ disabilities, $\quad$ (2004). $\quad$ Retrieved from http://www.dnis.org/features.php?issue_id=18\&volume_id=2\&features_id=57

[6] Equality and empowerment of women with disabilities. (n.d.). Retrieved from https://sustainabledevelopment.un.org/getWSDoc.php?id=3135

[7] Literacy rate for Persons with Disabilities. (n.d.). Retrieved from https://www.usaid.gov/what-we-do/genderequality-and-womens-empowerment/women-disabilities

[8] National Policy for Persons with Disabilities, (2006). Retrieved from https://www.ilo.org/dyn/natlex/docs/ELECTRONIC/93612/109496/.../IND93612.pdf

[9] National Policy for the Empowerment of Women (2001). Retrieved from http://wcd.nic.in/sites/default/files/National\%20Policy\%20for\%20Empowerment\%20of\%20Women\%202001.pdfNa yak, P \& Mahanta, B. (2009). Women Empowerment in India. Retrieved from https://www.researchgate.net/publication/23795416_Women_Empowerment_in_India

[10] Oxfam (Forthcoming). (n.d.). Women's Economic Empowerment Conceptual Framework. Retrieved from https://en.wikipedia.org/wiki/Women's_empowerment

[11] Persons with Disability Act (1995). Retrieved from http://newsonair.nic.in/PWD_Act.pdf

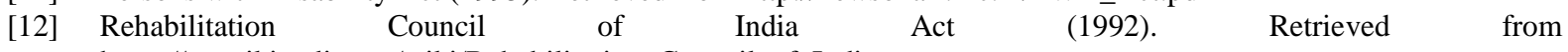
https://en.wikipedia.org/wiki/Rehabilitation_Council_of_India

[13] Right to Equality (Article 14-18) \& Right to Education (Article-21 A). (n.d.). Retrieved from https://en.wikipedia.org/wiki/Fundamental_rights_in_India

[14] Shettar, R. M. (2015). A Study on Issues and Challenges of Women Empowerment in India. Retrieved from http://iosrjournals.org/iosr-jbm/papers/Vol17-issue4/Version-1/B017411319.pdf

[15] Sonowal, M. K. (2013). Impact of Education in Women Empowerment: A Case Study of SC and ST women of Sonitpur District, Assam. Retrieved from http://caesjournals.org/spluploads/IJBASS-2013-008.pdf

[16] UN Convention on the Rights of Persons with Disabilities (CRPD). Retrieved from https://sustainabledevelopment.un.org/getWSDoc.php?id=3135 